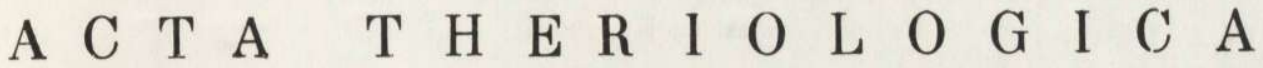 \\ VOL. XIV, 6: 63-68. \\ BIAEOWIEŻA \\ 5.IV.1969
}

\author{
Andrzej L. R U P R E C H T
}

\section{Taxonomic Value of Mandible Measurements in the Genus Plecotus Geoifroy, 1818}

[With 2 Figs. \& 1 Table]

The variability in the mandible dimensions has been investigated in bats of the genus Plecotus G e $\mathrm{f} \mathrm{froy}, 1818$ from Central Europe. The material consisted of 100 individuals of P. auritus and 100 individuals of $P$. austriacus. The variability in the mandible length appeared to be relatively low in both species $(C v=3.41-3.99)$, whereas that in the height of the ramus mandibulae was slightly higher $(C v=4.93-8.62)$. For both species the common values of the measurements of the mandible length are found in $10.8-11.0 \mathrm{~mm}$ classes, which contain 4 per cent of $P$. auritus and 18 per cent of $P$. austriacus. As to the height of the ramus mandibulae, the common range for both species falls to the $3.2 \mathrm{~mm}$ class ( 3 per cent of $P$. auritus and 4 per cent of P.austriacus). A complete separation of both species can be done by simultaneous comparison of two dimensions using the diagram of their correlation considering morphological characteristics of the mandible. This method may find practical application in indentifying fossil materials or those in owl pellets.

\section{INTRODUCTION}

Although European species of bats, namely Plecotus auritus ( $\mathrm{L}$ i n n a e u s, 1758) and Plecotus austriacus F is cher, 1829, may be considered as a typical pair of similar species, they nevertheless show some morphological differences. The number of characteristics distinguishing the two species seems to be definitely established (Topál, 1958; B a u e r, 1960; L a n z a, 1960; Hanák, 1962) and in the course of time their usefulness was confirmed by various authors (König \& König, 1961; van Bree \& Dulić, 1963; Corbet, 1964; Saint Girons, 1964; Ha nák, 1966; P i e chocki, 1966; S a c hlová, 1966; S te b bing s, 1967).

Identification of species based on conventional craniometric characters depends on the state of skulls. Therefore it seems reasonable to examine the taxonomic value of an element which cannot be easily damaged. In bats the mandible fulfills this condition, since despite frequent deficiencies in teeth it may remain undamaged in fossil materials or in owl pellets.

Two basic dimensions, the height of the ramus mandibulae and the mandible length have been used as complementary characteristics (König \& König, 1961, H a ná k, 1962; B e a u c or n u, 1963; R i ch ter, 1965; R u pre c h t, 1965; S c h mi d t, 1967). In both species, however, the intervals of their variability overlap somewhat. 
Having adequate comparative material at my disposal I made a new analysis of the applicability of those characteristics treating them jointly.

\section{MATERIAL AND METHODS}

The investigations were conducted on a series of skulls of P. auritus $(n=100)$ and $P$. austriacus $(\mathrm{n}=100)$ taken from Polish and Czechoslovak collections, but coming from Poland, Czechoslovakia and Bulgaria (Table 1). Three measurements were taken from each skull by means of vernier calipers: (1) the length of the maxillary tooth-row from $\mathrm{C}^{1}-\mathrm{M}^{3}$, (2) the length of the mandible from the anterior

Table 1.

Variability of mandible measurements (in $\mathrm{mm}$ ) in middle European representatives of Plecotus.

\begin{tabular}{|c|c|c|c|c|c|c|c|c|}
\hline \multirow{2}{*}{ Species } & \multirow{2}{*}{ Locum } & \multirow{2}{*}{$\mathrm{n}$} & \multicolumn{3}{|c|}{ Length of mandible } & \multicolumn{3}{|c|}{$\begin{array}{l}\text { Height of ramus } \\
\text { mandibulae }\end{array}$} \\
\hline & & & $\min .-\max$. & $\overrightarrow{\mathrm{x}} \pm \mathrm{SD}$ & $|C v|$ & $\min .-\max$ & $\overline{\mathrm{x}} \pm \mathrm{SD}$ & $C v$ \\
\hline P. auritus & $\begin{array}{l}\text { Poland } \\
\text { Czechoslovakia }\end{array}$ & $\begin{array}{l}54 \\
46\end{array}$ & $\begin{array}{l}9.4-10.9 \\
9.4-11.0\end{array}$ & $\begin{array}{l}10.29 \pm 0.37 \\
10.31 \pm 0.41\end{array}$ & \begin{tabular}{|l|}
3.63 \\
3.99
\end{tabular} & $\begin{array}{l}2.6-3.2 \\
2.6-3.1\end{array}$ & $\begin{array}{l}2.87 \pm 0.14 \\
2.84 \pm 0.24\end{array}$ & $\begin{array}{l}4.93 \\
8.62\end{array}$ \\
\hline P. austriacus & $\begin{array}{l}\text { Poland } \\
\text { Czechoslovakia } \\
\text { Bulgaria }\end{array}$ & $\begin{array}{r}25 \\
66 \\
9\end{array}$ & $\begin{array}{l}10.8-11.6 \\
10.8-11.9 \\
11.0-11.7\end{array}$ & $\begin{array}{l}11.22 \pm 0.39 \\
11.34 \div 0.44 \\
11.34 \pm 0.39\end{array}$ & $\begin{array}{l}345 \\
3.94 \\
3.41\end{array}$ & $\begin{array}{l}3.3-3.7 \\
3.2-3.7 \\
3.3-3.6\end{array}$ & $\begin{array}{l}3.43 \pm 0.17 \\
3.40 \mp 0.17 \\
3.45 \pm 0.22\end{array}$ & $\begin{array}{l}5.05 \\
5.09 \\
6.48\end{array}$ \\
\hline
\end{tabular}

edges of the alveolae $I^{1}$ to the end of the proc. condyloideus, s. articularis, (3) the height of the ramus mandibulae from the inc. praeangularis mandibulae to the top of the proc. coronoideus, s. muscularis ( $\mathrm{R} \mathrm{uprecht,1965).} \mathrm{The} \mathrm{accuracy}$ of the measurements amounted to $0.1 \mathrm{~mm}$. Mean values computed for both species from different populations were examined statistically by Student's $t$-test, for comparing means of independent groups.

\section{RESULTS}

The results obtained indicate that in both species the extreme lengths of the maxillary tooth-row are not overlapping. The boundary class being $5.6 \mathrm{~mm}$, but 6 per cent of $P$. auritus is found in the $5.5 \mathrm{~mm}$ class, and 5 per cent of $P$. austriacus belongs to the $5.6 \mathrm{~mm}$ class. This does not exclude the possibility that some extreme specimens belonging to one of the two species may exceed the value $5.6 \mathrm{~mm}$ (cf. also $\mathrm{L} \mathrm{a} \mathrm{nz} \mathrm{a,}$ 1960; Sa int Girons, 1964).

The ranges of the mandible length and of the height of the ramus mandibulae overlap in both species (Table 1, Fig. 1). It has been stated, however, that the values of the mandible length does not overlap to the extent observed by $\mathrm{H}$ a $\mathrm{n}$ à $\mathrm{k}$ (1962). The common values of mandibular length are in the $10.8-11.0 \mathrm{~mm}$ classes, which embrace 4 per cent of $P$. auritus and 18 per cent of $P$. austriacus (Fig. 1). 
The $3.2 \mathrm{~mm}$ height of the ramus mandibulae is in a class common to both species. This class contains 3 per cent of $P$. auritus and 4 per cent of P. austriacus (Fig. 1).

Fig. 1. Correlation between two mandible measurements (length and height) in Plecotus.

- P. austriacus, - P. auritus.

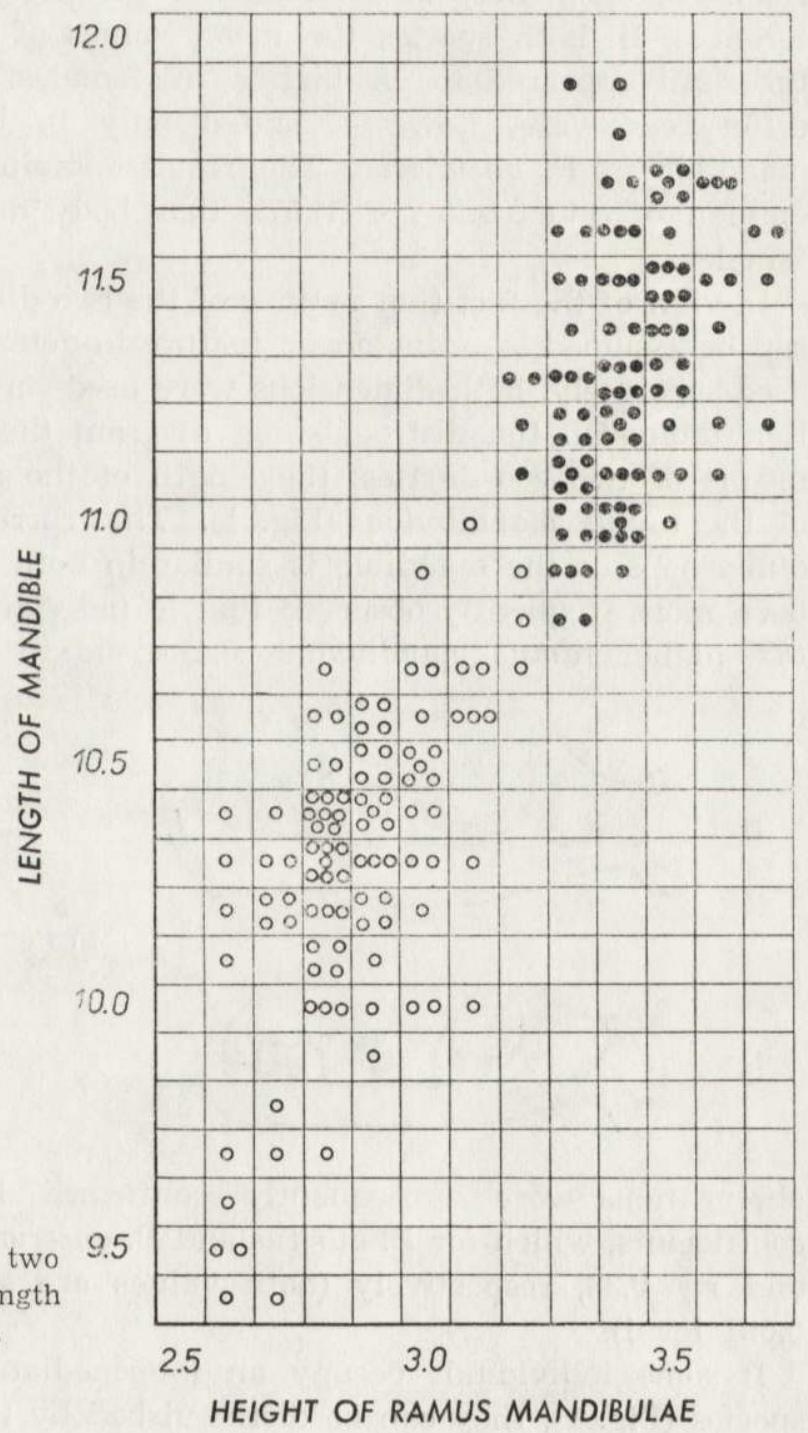

In the populations of both species investigated the ranges of the coefficient of variation show a relatively small variability in the length of the mandible $(C v=3.41-3.99)$ and a somewhat greater one in the height of the ramus mandibulae $(C v=4.93-8.62)$.

5 - Acta theriol. 
The mean values of three measurements for different populations show no statistically significant differences (Table 1). The variability in the dimensions of the skull, analysed in geographical aspects (cf. H a nák, 1966), may be affected not only by age but also by sex differences. In both species the mean values of the three dimensions of the skull appeared to be higher in females. Statistically significant differences were, however, stated only in both dimensions of the mandible in $P$. austriacus. The results obtained seem to confirm the opinion of Stebbing s (1967), that body dimensions are greater in females.

In view of the fact that neither of the two dimensions of the mandible can be assumed as a diagnostic feature in determining the species when used separately, both dimensions were used simultaneously in a correlation table. On the distinguishing diagram the specimen is defined by means of two coordinates: the length of the mandible and the height of the ramus mandibulae (Fig. 1). The correlation between the two dimensions of the mandible is similar in both species. It has, however, been more frequently observed that in individuals belonging to P. auritus, higher ramus mandibulae correspond to longer mandibles. Those

a

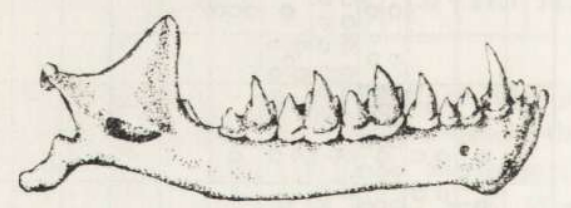

Fig. 2. The shape of the mandible in Plecotus. a - P. austriacus, bP. auritus.

b

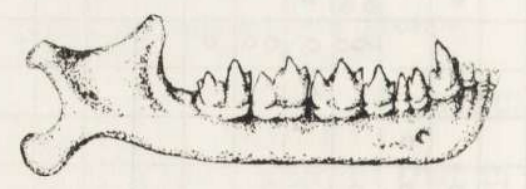

observations were subsequently confirmed by computed correlation coefficients, which for $P$. auritus and $P$. austriacus amounted to $r=0.61$ and $r=0.38$, respectively (both values are statistically significant at 0.001 level).

If some individuals occupy an intermediate zone between the two species (Fig. 1), they can be distinguished by the following morphological characters:

P. austriacus - proc. angularis mandibulae long, distinctly directed outward, blunt, median portion with a well-marked horn.

$P$. auritus - proc. angularis mandibulae short, less distinctly directed outward, ending with a club-shaped widening, its median portion does not possess a distinct horn (Fig. 2; R u p e cht, 1965). 


\section{DISCUSSION}

As reported by $\mathrm{H}$ an ák (1966) the representatives of the genus Plecotus are characterized by geographical variability in the condylo-basal length and bulla tympanica length. It seems probable that other dimensions of the skull may illustrate geographical variability of both species, depending on the degree of their correlation with the condylo-basal length.

The analysis to which the material investigated has been subjected, shows that bats from Poland, Czechoslovakia and Bulgaria are not highly differentiated (Table 1). None of the differences in the dimensions of the mandible investigated in different populations of both species appeared statistically significant. The data obtained confirm the low morphologic variability in Central European populations of the genus Plecotus (cf. also $\mathrm{H}$ a nák, 1966).

The relationship between the condylo-basal length and the mandible length ( $P$. auritus $-r=0.7665, P$. austriacus $-r=0.8042)$ is of a great importance in practical application of the distinguishing diagram, especially since, according to $\breve{S}$ a chlova (1966), the effect of size on body proportions is identical in both species. In practical application of the diagram it should be realized that populations of both $P$. auritus and $P$. austriacus may show brachycephalic or dolichocephalic tendencies within their geographical ranges ( $\mathrm{H}$ a $\mathrm{n}$ a $\mathrm{k}, 1966)$, these may be associated with proportional decrease or increase in mandible measurements.

Considering the weak differentiation between the Central European populations of both species, it seems that the distinguishing diagram will find its practical application at least in Central Europe.

Acknowledgements: The author is particularly indebted to Professor Dr. K. K owalski, Dr. W. Harmata, B. W. Woloszyn (M. Sc.) as well to Dr. J. $\mathrm{G}$ a is ler and Dr. V. Ha nák for making him available their collections for this comparative study. The gratitude is expressed to Dr. Z. Pucek for critical examination of the first draft of this paper, and Dr. G. L. D r y den (Slippery Rock College) for reading of the manuscript and valuable corrections of the text.

\section{REFERENCES}

1. B a u e r K., 1960: Die Säugetiere des Neusiedlersee-Gebietes (Österreich). Bonn. zool. Beitr., 11, 2-4: 141-344.

2. Beaucornu J. C., 1963: Sur la présence dans l'Ouest (Sarthe, Maine-et-Loire et Ille-et-Vilaine) de l'Oreillard meridional Plecotus austriacus F is cher, 1829 (Chir., Vesp.), signalé en France de Nice, du Delta rhodanien et de Corse. Bull. Soc. Sci. de Bretagne, 38: 165-171.

3. Bree P. J. H. \& Dulić B., 1963: Notes on some specimens of the genus Plecotus Geoffroy, 1818 (Mammalia, Chiroptera) from the Netherlands. Beaufortia, 10, 113: 7-18. 
4. Corbet G. B., 1964: The Grey Long-eared bat Plecotus austriacus in England and the Channel Islands. Proc. zool. Soc. Lond., 143, 3: 511-515.

5. H a nák V., 1962: Netopyr dlouhouchý (Plecotus austriacus Fischer, 1829) - nový člen naši savči fauny. Cas. Nár. muzea, oddil přirov., 131, 2: 87-96.

6. Hanák V., 1966: Zur Systematik und Verbreitung der Gattung Plecotus, Ge offroy 1818 (Mammalia, Chiroptera). Lynx, 6: 57-66.

7. König C. \& König I., 1961: Zur Ökologie und Systematik südfranzösischer Fledermäuse. Bonn. zool. Beitr., 12, 3-4: 189-228.

8. Lanza B., 1960: Su due specie criptiche di Orecchione: "Plecotus auritus,, (L.) e "P. Wardi, Thom a s ("Mamm.; Chiroptera,,). Mon. zool. Italiano, 68, 1-2: $7-23$.

9. Piechocki R., 1966: Úber die Nachweise der Langohr-Fledermäuse Plecotus auritus L. und Plecotus austriacus $\mathrm{F}$ is cher im mitteldeutschen Raum. Hercynia, 3, 4: 407-415.

10. R i chter H., 1965: Das Graue Langohr, Plecotus austriacus F is cher, 1829, in der Magdeburger Börde und in Sachsen. Säugetierkdl. Mitt., 13, 1-2: $5-8$.

11. Ruprecht A., 1965: Metody wyróżniania Plecotus austriacus Fischer, 1829 i nowe stanowiska tego gatunku w Polsce. Acta theriol., 10, 14: 215-220.

12. S a chlová D., 1966: Mezidruhové allometrické vztahy u rodu Plecotus (Microchiroptera). Lynx, 6: 153-159.

13. S a int Girons M. C., 1964: Sur la répartition en France de Plecotus austriacus F is cher, 1829, l'Oreillard méridional. Mammalia, 28, 1: 101-108.

14. Schmidt A., 1967: Uber das Graue Langohr, Plecotus austriacus F is cher, 1829, in Brandenburg. Ztschr. Säugetierkde, 32, 4: 246-250.

15. Stebbing s R. E., 1967: Identification and distribution of bats of the genus Plecotus in England. J. Zool. Lond., 153: 291-310.

16. Topál G., 1958: Morphological studies on the os penis of bats in the Carpathian Basin. Annls Hist.-Nat. Mus. Nat. Hung., 50: 331-342.

Received, October 1, 1968.

Polish Academy of Sciences,

Mammals Research Institute,

Białowieża, woj. Białystok.

Andrzej L. RUPRECHT

\section{TAKSONOMICZNA WARTOŚC POMIAROW ŻUCHWY PRZEDSTAWICIELI RODZAJU PLECOTUS GEOFFROY, 1818}

Zbadano zmienność wymiarów żuchwy nietoperzy z rodzaju Plecotus Ge offr o y, 1818, z obszaru Europy środkowej $(n=100 P$. auritus i $n=100 P$. austriacus). U obu gatunków stwierdzono stosunkowo małą zmienność długości żuchwy $(C v=3,41-3,99)$ i nieco wyższą $\mathrm{w}$ wysokości ramus mandibulae $(C v=4,93-8,62)$. Wartości pomiaru długości żuchwy są wspólne dla obu gatunków w klasach 10,8$11,0 \mathrm{~mm}$, zawierających $4 \%$ P. auritus i $18 \%$ P. austriacus. W wysokości ramus mandibulae, wspólny zakres dla obu gatunków przypada na klasę $3,2 \mathrm{~mm} \quad\left(3^{\circ} \%\right.$ $P$. auritus i $4 \%$ P. austriacus). Całkowite rozdzielenie obu gatunków umożliwia równoczesne porównanie dwu pomiarów przy pomocy diagramu ich korelacji, z uwzględnieniem cech opisowych żuchwy. Metoda ta może znaleźć praktyczne zastosowanie dla oznaczania materiałów kopalnych, względnie pochodzących z wypluwek sów. 